\title{
Instructional Leadership and Capacity Building for Teaching Quality
}

\author{
Ajat Sudrajat* \\ Educational Administration Department \\ School of Postgraduate, Universitas Pendidikan Indonesia \\ Bandung, Indonesia \\ *ajattea392@gmail.com
}

\author{
Abubakar \\ Universitas Pendidikan Indonesia \\ Bandung, Indonesia
}

\begin{abstract}
This research aimed at finding the correlation between instructional leadership and capacity building along with teaching quality improvement, both as an individual or as a team. It deployed a survey method conducted among 170 primary school teachers of Cluster 01 in Cikampek, Karawang using proportional random sampling, from which 119 respondents were taken as samples. The data collected were then analyzed using simple regression, multiple regression, simple correlation, multiple correlation, and partial correlation tests. It resulted in three conclusions. First, it showed that there was a positive correlation between instructional leadership and teaching quality improvement satisfaction shown by the correlation coefficient $r_{y 1}=0.5074$ and the coefficient of determination $\mathbf{r}_{\mathbf{y} 1}^{2}=\mathbf{0 . 2 5 7 4}$. Second, it showed that there was a positive correlation between teacher's capacity building and teaching quality improvement which was shown by the correlation coefficient $\mathbf{r}_{\mathbf{y} 2}=\mathbf{0 . 5 8 0 0}$ and the coefficient of determination $\mathbf{r}^{2}{ }^{2}=0,3364$. Third, it found that there was a positive correlation between instructional leadership and capacity building as well as teaching quality improvement which was shown by correlation coefficient $r_{y 1.2=0,6695}$ and the coefficient of determination $r^{2}=0,4482$.
\end{abstract}

Keywords-instructional leadership, capacity building, the improvement of teaching quality

\section{INTRODUCTION}

Education is investation in human resources development and is viewed as a primary need of people who want to achieve advancement. The National Education aims at improving the quality of Indonesians to become religious, virtuous, independent, intelligent, creative, skilled, and disciplined. According to Amri, the components of education are curriculum, teacher, and student [1]. In learning process, teacher's existence is very urgent as the teacher determines the achievement of learning objectives and the achievement of student competencies. Therefore, it can be said that the teacher has an important role in controlling the achievement of learning objectives and student competencies.

Teachers are the main factor that must be considered in improving the quality of learning because they have a strategic important role in guiding students. They are not only expected to master teaching materials and have educational technical skills, but also expected to have reliable personality and integrity so that they become role models for students, family, as well as society. While teaching, teachers must be able to create a pleasant learning atmosphere in addition to providing explanations about the lesson so as to be easily understood by students.

Besides, teachers are required to have the standard of knowledge which meets changes in society and developments in science and technology. Moreover, during today's Information Age, openness in almost all aspects and systems of life cannot be prevented. Likewise, the parameters of the quality of education, in terms of input, process, output, and results, always change from time to time. Therefore, the quality of national education needs to be continuously improved, starting from primary education to higher education by means of various clear and quality policies and decisions.

Professional teachers must have special abilities and expertise in teaching training so as to be able to effectively carry out their duties and function. Improving teacher's professionalism can be carried out through an internal approach such as collaboration with peers which can be done formally or informally to discuss many educational issues or problems, including cooperation in any other issues (for example, planning, implementing, and evaluating school programs). It can also be carried out by means of external approach, such as taking part in training, workshops, or further studies.

Teachers as educators are professionals who are in charge of planning and implementing the learning process, assessing learning outcomes, providing guidance and training, as well as conducting research and community service. Teachers are obliged to develop and utilize their professional abilities, in order that they can improve their performance in carrying out their duties and functions because future education requires excellent professional teachers.

Based on the orientation of educational process standard, according to W. Sanjaya, learning process is a system [2]. Thus, the format of the standard process for improving the quality of education can be started from all components that 
shape and affect learning processes. All along, the most influential component in education process has been teachers. This is because teachers are the spearhead which deals directly with students as learning objects and subjects.

Meanwhile, the reports from the Regional Coordinator for Education (Korwilbidik), Cikampek District, Karawang Regency in the 2020-2021 academic year showed the data about the reasons of low quality teaching. As an additional information, in this academic year, the country was being hit by a biological disaster Coronavirus diseases (Covid-19) which also affected education, where the implementation of usual face-to-face learning was not allowed, and online or internetbased teaching had to be carried out instead. Some obstacles that caused the low quality teaching include: (1) The limited intensity of communication between teachers and students (17\%); (2) interaction and discussion among teachers (18\%); (3) e-learning-based curriculum management which had not been optimally understood (35\%); and (4) school managers who lacked of initiative to take curricular policies when mass e-learning had to be implemented (30\%). As a result, teachers' productivity and learning achievement declined.

Many factors were thought to be able to affect the improvement of teaching quality especially in this limited circumstance, one of which was instructional leadership. Instructional leadership is one type of leadership that emphasizes or focuses on learning. The components of instructional leadership include curriculum, teaching and learning processes, assessment, teacher development, excellent service in learning, and learning communities development in schools [3].

Instructional leadership is also called education leadership, school leadership, visionary leadership, teaching-learning leadership, and supervision leadership [4]. In teacher context, schools and classrooms are an organization, where the teacher is the leader in learning processes. Instructional leadership by the principal aims to guide teachers in conductiong learning to achieve educational goals which include curriculum, teaching and learning process, assessment, teacher development, excellent service in learning, and development of learning communities in schools to achieve the already set vision well. The principal must have the ability to develop learning programs as well as to analyze, develop, and comprehend the content of the curriculum.

Besides instructional leadership, teacher capacity building can also affect the quality of teaching. Teacher's capacity building means the steps to improve the ability of teachers to analyze the conditions of learning environment and to identify problems and needs by monitoring and evaluating learning in order to get feedback. In another sense, teacher capacity building means a strategy for delivering teaching materials. Thus, organizing teaching materials in the context of learning management is a process of manifesting, maintaining, preserving, and developing learning strategies to achieve learning objectives bound by student satisfaction.
From the above explanation, this report will depict intructional leadership and capacity building in improving teaching with the aims of finding out whether there was a correlation between:

- Instructional leadership and teaching quality improvement;

- Capacity building and teaching quality improvement;

- Intructional leadership and capacity building as well as teaching quality improvement.

\section{THEORETICAL REVIEW}

\section{A. Instructional Leadership}

The main activity carried out at schools are learning. Learning activities cannot take place effectively when there is no leader. Leaders in school institutions or principals, must have an innovative and visionary role in carrying out education in schools, because the duty of a principal is to lead the school to be a place for teaching and learning between teachers and students. One of the principal's duties is instructional leadership.

Instructional leadership, according to Eggen and Kauchak [5], is an action taken by (the principal) to develop a productive and satisfying work environment for teachers which in turn can create better student learning conditions [6]. Principals must create a conducive and harmonious atmosphere in school between leader and teachers, teachers and teachers, and also teachers and students. When the atmosphere is built in harmony, learning processes will take place effectively and will ultimately improve teaching quality.

Meanwhile, Daresh and Playco [6] states that intructional leadership is an effort to lead teachers to teach better, which in turn can improve student learning achievement. Teachers expect teaching guidance from principals in order that learning processes can run well. Principals cannot implement institutional goals without the support from teachers. Thus, leaders must be able to motivate teachers so that the institutional goals can be attained.

Meanwhile, according to Bush and Glover [7], instructional leadership is a type of leadership that stresses on components closely related to learning, including curriculum, teaching and learning process, assessment, teacher development, excellent service in learning, and the development of learning communities in schools. Technical guidance of school administration is adjusted to the national education standards, that is teachers can implement school curriculum according to the applicable spectrum. Teaching and learning preparation must also be prepared, for example making syllabus and learning program units, making lesson plans, providing assessment or evaluation, reactive education administration services so that the learning processes can be well-structured and productive resulting in learning satisfaction [8]. 
Besides, Hellinger [9] defines effective intructional leadership as follows:

- The meaning of the school's vision by sharing opinions with school community and striving for schools' vision and mission to maintain the implementation;

- Principals involve stakeholders in school management (participatory management);

- $\quad$ Principals provide support for learning;

- Principals monitor teaching and learning processes to understand more deeply and be aware of what is going on in schools;

- Principals act as a facilitator so that in various ways he can be able to identify teaching and learning difficulties and can assist teachers in overcoming them [3].

Additionally, Soutworth [8] states that instructional leadership is a strong concern of a leader for teaching and learning, including professional learning by teachers in accordance with student development. Principals provide support for learning, for example principals decides that teaching focusing on student learning interests must be prioritized.

He added that leadership in learning will be more effective if principals are able to play their roles as: (1) the monitor of teacher performance, principals must monitor teachers in carrying out their duties and functions; (2) the assessor of teacher performance, this is one of the principal roles that are objective and careful in evaluating teacher performance; (3) the executor and the arranger in mentoring and training, this is the role of principals in conducting supervision; (4) the planner of teacher sustainable professionalism development, this is the role of principals in improving teacher professionalism in a sustainable manner; (5) the coordinator of team work, principals coordinate the team at schools; (6) the coordinator of effective learning, principals become the learning leader in schools, striving for teachers to implement effective learning.

The main objective of instructional leadership is to facilitate learning so that students' learning achievement increases, learning satisfaction gets higher, learning motivation gets higher, curiosity is answered, creativity is fulfilled, innovation is manifested, entrepreneurial spirit is formed, and awareness for lifelong learning is developed because science, technology, art grow well and rapidly.

The success of an effective principal as a learning leader is: (1) as the provider of resources, being able to manage time and class conditions, as well as to motivate teachers; (2) as the instructional resource, improving effective classroom conditions to boost learning outcomes; (3) as the communicator, being able to understand and convey school vision and goals to teachers; and (4) having meaningful presence, being able to interact and influence all school community (6).
Based on the previous explanation, what is meant by instructional leadership is the harmonious constructive actions taken by principals in encouraging and caring for teachers to teach in accordance with professionally applicable curriculum standards to improve student learning achievement. The indicators are (1) a conducive learning atmosphere, (2) intellectual stimulation, (3) paying attention to school needs, (4) inspiring, (5) having a realistic vision, (6) developing a culture of cooperation, and (7) communcating persuasively.

\section{B. Capacity Building}

Capacity is someone's ability to do something in order to achieve goals. This is reinforced by the opinion expressed by Milen who said that capacity is defined as the ability of individuals, organizations, or systems to carry out their proper functions efficiently, effectively, and continuously in order to achieve certain goals [10]

Meanwhile, the meaning of building is an action, process, result, or something that shows progress, improvement, development, and growth. According to Bennis, the essence of building is a response to reality. Building is carried out to change beliefs in attitudes, values, and structures. It is for the better. It is adaptive and flexible because it must be in accordance with the probability of times [11]. Therefore capacity building is a process that can increase the ability of an individual, an organization, or a system to achieve goals.

Capacity building is a process for doing something or a series of movements, multilevel changes within individuals, groups, organizations, and systems in order to strengthen the adaptability of individuals and organizations so that they can be responsive to changes in their surrounding [12]. Capacity building is closely related to improving the quality of human resources, as an effort to encourage the organization to function properly, as well as an effort to create the environment needed by the organization to function properly.

The similar ideas are stated by Sessions Kathy [13] who defines that:

"Capacity building is usually understood to mean helping governments, communities, and individuals to develop the skills and experience needed to achieve their goals. Capacity building programs, often designed to strengthen participant's abilities to evaluate their policy choices and implement decisions effectively, which may include education and training, institutional and legal reforms, as well as scientific, technological, and financial assistance."

From the previous explanation, it can be understood that capacity building is an effort to help the government, community, or individuals to develop the skills and expertise needed to achieve goals.

Brown Haryanto [14] explains capacity building as a process that can increase the ability of a person, an organization, or a system to achieve goals. 
Currently the effort to build capacity is an important part of various aspects of education, the main objective of which is to make quality and desirable educational institutions. Capacity building, therefore, is related to the efforts to develop quality education and its surrounding systems.

Capacity building refers to the process by which individuals, groups, organizations, institutions and communities develop their abilities both individually and collectively to carry out their functions, solve their problems, and achieve their goals independently.

Thus, what is meant by capacity building in improving the quality of education here is the process of building the capacity of institutions carried out by principals in order to increase the ability of individuals, organizations, communities to achieve the vision, mission, goals, objectives, outputs, and outcomes that have been determined.

Factors that affect capacity building, especially in educational institutions, include 5 (five) main points: mutual commitment, leadership, regulatory reform, institutional reform, and acceptance of strengths and weaknesses [15].

First, mutual commitment. It is the involvement of all organizational actors in supporting the success of institutional capacity building programs. Second, leadership. Conducive leadership is the primary point in determining the success of an institution's capacity building programs to initiate ideas to achieve the desired organizational goals. Third, regulatory reform. The leader's mindset and the culture of the institutional employeees who always take cover behind the existing regulations as well as various legal-procedural factors from the government can inhibit the success of institutional building programs. Fourth, institutional reform. It essentially refers to the development of conducive climate and culture for the implementation of personal and institutional capacity programs in order that the desired objectives can be achieved. Fifth, acceptance of strengths and weaknesses. The institutional capacity building process begins with the identification of the capacities existance. Therefore, organizations and individuals must transparently state the strengths and weaknesses. Openness about the capacity conditions is very important because the success of institutional capacity building programs starts from honesty and validity in pointing out the strengths and weaknesses of the current capacities.

\section{The Improvement of Teaching Quality}

Quality means level, grade of whether something or someone is good or bad [16]. According to Permadi, quality in education is relative and not absolute. In other words, the quality of education will be good and satisfying if it meets or exceeds the needs of the customers (teachers, staff, students, and community).

In the the Great Dictionary of the Indonesian Language (KBBI), the term 'teacher' is defined as a person whose job (livelihood) is teaching. The definition of teaching according to S. Nasution [17] is firstly, imparting knowledge to students, aiming that this knowledge can be mastered as best as possible by students. Teaching in this sense is considered successful if students master the knowledge transferred by the teacher as much as possible. Secondly, teaching is conveying culture to students. The second definition is essentially the same as the first definition which emphasizes the teacher as an active party. Thirdly, teaching is an activity to organize or manage the environment as best as possible and connect it with students so that the learning process occurs.

From the definitions, it can be concluded that teaching is an activity of imparting information knowledge from teachers to students in a structured manner so that students can find out and develop their knowledge.

The definition of teacher quality is the quality level of an educator in providing education and learning to students in order to fulfill their authority and responsibilities both at school and outside of school. Meanwhile, in the Constitution No. 14 of 2005 it is stated that teachers are professional educators whose main tasks are educating, teaching, guiding, directing, training, assessing, and evaluating students from early childhood education through formal education, primary education, and secondary education. In addition, teachers have a position as professional staff at the levels of primary education, secondary education, and early education in formal education, appointed by statutory regulations, and teachers are required to have academic qualifications, competencies, and educational certificates, be physically and mentally healthy, and have the ability to reach the goals of national education [18].

According to Nanang Hanifah and Cucu Suhana in their book Konsep Strategi Pembelajaran (the Concept of Learning Strategies), indicators in education include input, process, and output of education. Educational input is anything that must be available because it is needed for the process to take place. Educational input includes human resources (principal and organigrams in schools) and other resources (equipment, supplies, money, and materials). The educational process includes the formation of curricula and other learning tools. The educational output includes the vision, mission, goals, and targets that schools want to achieve.

Quality in educational context refers to the achievements achieved by students or schools at particular time. Achievements or educational outcomes (student achievement) can be in the form of academic test results (for eample general tests and National Examination). It can also be in the form of achievements in other fields, such as in sports, art, or any other skills [19]. Factors that affect the quality of teaching include (1) knowledge, (2) the ability to make lesson plans, (3) the ability to use media or learning aids, (4) the ability to apply methods, (5) the ability to manage classrooms, and (6) the ability to evaluate [20].

Meanwhile, the quality achieved by students is influenced by internal and external factors. These factors include following points. 
- Resources. Schools must be flexible in managing all resources which meets the needs, such as operational financing and financial management to strengthen schools in determining and isolating funds according to the priority scale that has been set for the quality improvement process.

- Accountability. Schools are required to have a commitment to the standards of success and expectations or demands of parents or society. This accountability aims to ensure that public funds are used in accordance with predetermined policies in order to improve the quality of education and, if possible, to provide information about what the schools have done.

- Curriculum. Based on national curriculum standards, schools are responsible for developing curriculum from bpth the content aspect as well as the process of delivery. The material has to be beneficial and relevant to students. Schools must create a pleasant learning atmosphere and involve all senses and layers of the brain and create challenges in order that students will grow and develop intellectually by mastering knowledge and skills, and by having good attitude, characters, and emotional maturity.

\section{RESEARCH METHODOLOGY}

The research method used in this study was a survey method with correlational approach, which is a type of research that seeks to suggest whether or not there is a correlation between the independent variable and the dependent variable. The independent variables in this research were instructional leadership and capacity building. Meanwhile the dependent variable is the improvement in teaching quality.

The instrument utilized for the three research variables was questionnaire in the form of a list of statements given to respondents according to the specified sample. The questionnaire was a closed questionnaire with provided answers using a Likert scale so the respondents only needed to choose one answer based on their opinion. The respondents were public primary school teachers Cluster 01 who were civil servants in Cikampek District, Karawang Regency.

The constellation of the correlation between the three research variables is shown in the following Figure 1.

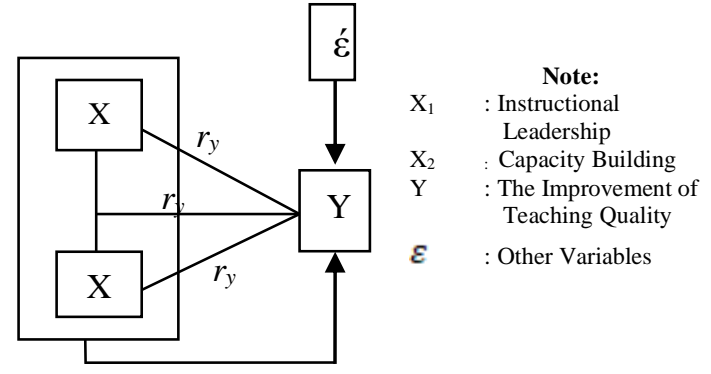

Fig. 1. The constellation of research problems.
This research included 170 teachers, so the sampling used proportional random sampling and was carried out by lottery. Meanwhile, the sampling technique utilized the Slovin's formula with error margin $=5 \%$. The formula is as follows.

$$
\mathrm{n}=\frac{\mathrm{N}}{1+\mathrm{N} \cdot \mathrm{e}^{2}}
$$

Where:

$\mathrm{n}=$ number of sample

$\mathrm{N}=$ total population

$\mathrm{e}=$ the desired critical value (accuracy limit) which is $5 \%$

Based on the formula, here is the calculation of the sampling.

$$
\begin{aligned}
& \mathrm{n}=\frac{\mathrm{N}}{1+\mathrm{N} \cdot \mathrm{e}^{2}}=\frac{170}{1+170(0.0025)} \\
& \mathrm{n}=\frac{170}{1.42} \quad=119.41 \rightarrow \text { rounded off }=119 \text { respondents. }
\end{aligned}
$$

The technique used was conducted by distributing a questionnaire to determine the variables: the improvement of teaching quality, instructional leadership, and capacity building.

\section{RESULTS AND DISCUSSION}

\section{A. The Correlation between Instructional Leadership and the Improvement of Teaching Quality}

To test the hypothesis that there was a positive correlation between variable $\mathrm{X}_{1}$ and variable $\mathrm{Y}$, it was important to test the significance of the correlation coefficient utilizing $t$ test. The results of the calculation with $\mathrm{n}=119, \mathrm{t}$ value $=6.3688$ was obtained, while $t_{\text {table }}=1.980(\alpha=0.05)$, and $t_{\text {table }}=2.617(\alpha=$ $0.01)$ which means that the correlation coefficient between learning leadership $\left(\mathrm{X}_{1}\right)$ and the improvement of teaching quality (Y) was very significant. Thus, there was a very significant positive correlation between instructional leadership and teaching quality improvement.

The significance of the correlation between instructional leadership and the improvement of teaching quality was indicated by the correlation coefficient $\left(r_{y 1}\right)=0.5074$ and the coefficient of determination $\left(\mathrm{r}_{\mathrm{y} 2}^{2}\right)=0.2574$. This means that $25.74 \%$ of improvement of teaching quality could be resulted from the existence of instructional leadership. Meanwhile, $74.26 \%$ of teaching quality improvement was influenced by other factors.

The synthesis theory of instructional leadership in this research was that instructional leadership was the harmonious constructive actions taken by principals to give encouragement and attention to teachers to carry out their teaching in accordance with professionally applicable curriculum standards to improve student learning achievement. The purpose of 
instructional leadership is for the leaders to create a conducive learning atmosphere, provide intellectual stimulation, give attention to school needs, inspire, have a realistic vision so that cultures of cooperation and persuasive communication can be developed.

Teacher are the spearhead of the implementation of teaching and learning process in schools. The level of student achievement is closely related to teaching quality, so teachers should work comfortably, have a positive attitude, have supportive colleagues, and have targets to be achieved in accordance with the vision and mission of education. The improvement of teaching quality cannot be achived without several important factors, one of which is the instructional leadership. Components of instructional leadership such as curriculum, teaching and learning processes, assessment, teacher development, excellent service in learning, and the development of learning communities in schools are genuinely needed to improve the quality of teachers in carrying out their duties.

Improving teaching quality is essential in today's competitive world. Schools will be better if human resources such as teachers and other school community become more effective and efficient at work and are satisfied both essentially and financially. An instructional leader means a leader who inspires, develops, and empowers teachers in two ways: achieving extraordinary results and being able to develop the leadership capacities of their subordinates. Additionally, an instructional leader also helps teachers to grow and develop into leaders by responding to their needs through empowering and aligning the needs of teachers, leaders, and organizations.

The quality of teaching reflects the teachers' efforts or actions to make better learning. Basically, schools want teachers who can work optimally so that schools' goals can be achieved. However, the achievement depends on how principals guide the teachers to attain the goals with high productivity. Therefore, principals who have instructional leadership can help teachers to improve the quality of their performance.

Based on the previous explanation, it can be inferred that instructional leadership is one of the determining factors for teachers to carry out their duties, especially in improving teaching quality.

\section{B. The Correlation between Capacity Building and the Improvement of Teaching Quality}

To test the hypothesis about positive correlation between variable $\mathrm{X}_{2}$ and variable $\mathrm{Y}$, it was necessary to test the significance of the correlation coefficient using t test. The calculation showed $\mathrm{t}$ value $=7.7019$ while $\mathrm{t}$ table $=1.980(\mathrm{n}=$ 119 and $\alpha=0.05)$, and $\mathrm{t}$ table $=2.617(\mathrm{n}=119$ and $\alpha=0.01)$ which means that the correlation coefficient between capacity building $\left(\mathrm{X}_{2}\right)$ and the improvement of teaching quality $(\mathrm{Y})$ was very significant. Thus, there was a very significant positive correlation between capacity building and the improvement of teaching quality.
The significance of the correlation between capacity building and improvement of teaching quality was indicated by the correlation coefficient $\left(\mathrm{r}_{\mathrm{y} 2}\right)=0.5800$ and the coefficient of determination $\left(\mathrm{r}^{2} \mathrm{y} 2\right)=0.3364$. This means that $33.64 \%$ of teaching quality variable could be resulted from the variable of teacher capacity building. Meanwhile, $66.36 \%$ of teaching quality improvement variable was influenced by other factors.

Capacity building is the process of building institutional capacity carried out by principals in order to increase the ability of individuals, organizations, communities to achieve vision, mission, goals, objectives, outputs, and outcomes. The indicators are (1) commitment, (2) leadership, (3) regulation, (4) transparency, and (5) partnership.

Improved quality teaching can be reflected in the teacher's attitude towards their work and towards everything they face in schools. Teachers who work enthusiastically when they have the autonomy to act will work comfortably, safely, and be in an environment that supports the achievement of goals. Improving teaching quality is influenced by a lot of factors including (1) knowledge, (2) the ability to make lesson plans, (3) the ability to use media or learning aids, (4) the ability to apply methods, (5) the ability to manage classrooms, (6) and the ability to evaluate. In other words, there is an element of capacity building in order that teachers can work well because all needs are met.

To improve the quality of teaching, schools must respond to the needs of teachers by providing training and supervision to increase teachers' professional competence. Therefore, if capacity building variable highly increases, the improvement of teaching quality will indirectly be achieved. Based on the description above, teacher capacity building is one of the dominant determinants for teachers in improving their teaching quality.

\section{Instructional Leadership, Capacity Building, and Improving Teaching Quality}

The result of the third hypothesis that there is a positive correlation between variable $\mathrm{X}_{1}$ and variable $\mathrm{X}_{2}$ along with variable $\mathrm{Y}$ is shown by the correlation coefficient $\left(\mathrm{r}_{\mathrm{y} 12}\right)=$ 0.6695 and the coefficient of determination $\left(\mathrm{r}^{2}\right)=0.4482$. It means that $44.82 \%$ of teaching quality improvement variable can be generated from instructional leadership and teachers' capacity building variables. Meanwhile, $55.18 \%$ of the improvement of teaching quality variable was affected by other factors.

Improving teaching quality is an effort to achieve the quality of an educator to provide education and learning for students in a structured and responsible manner to achieve learning objectives perfectly. The indicators are (1) having insight, (2) having the ability to arrange learning tools, (3) having class managerial skills, (4) responsibility, and (5) innovation in teaching.

The support of instructional leadership for improving teaching quality is very necessary in schools so that teachers 
can work with high morale, be comfortable, become very dedicating, and live up to their profession. Satisfied teachers who try to improve the quality of their teaching because they are influenced by the leader will be able to influence their followers to achieve organizational goals, believe in disciplined thinking and needs of careful problem analysis, and believe in a vision which is trusting the intuition of its members. Principals' positive attitude can encourage, direct, and motivate all school community to cooperate in reaching the vision, mission, and goals of the school. In education, contented teachers will work with high loyalty, show a positive attitude towards working, perform better than other teachers, be helpful even outside of school hours. Therefore, school leaders can use the teacher's contentedness to improve the quality of education in schools in order that they can compete with other schools.

Capacity building is the development which contributes to increasing the ability/competence of teachers which in turn will have an impact on increasing the quality of teaching. King and Cuttence Newmann [21] argue that in improving the teaching process, capacity building can contribute through the following: 1) improving the knowledge, skills, and disposition of individual staff members 2) organized, collective enterprise arising from a strong, school-wide professional community and 3 ) focused, coherent, and sustained staff and student learning. Therefore, the efforts made by teachers in building their capacity as educators are a very important factor, as it can increase the abilities and competencies of educators/teachers, which in the future will lead to the improvement of learning process. Building professional educators requires increased competence, especially the competence to deal with problems in classrooms, and learning innovation which is important.

Therefore, capacity building is a process to do something, or a series of movements, multilevel changes within individuals, groups, organizations, and systems, which aims to strengthen the adaptability of individuals and organizations to be responsive to the surrounding changes. Capacity building is closely related to improving the quality of human resources as an effort to encourage the organization to run according to its function, as well as an effort to create the environmental conditions needed by the organization to function properly.

Based on the discussion, it can be safely assumed that there is a positive correlation between instructional leadership and capacity building along with the improvement of teaching quality.

\section{CONCLusion, Suggestion, AND RECOMMENDATION}

\section{A. Conclusion}

From this reserach, it was found that instructional leadership was only able to contribute to improving the teaching quality by $25.74 \%$, while $74.26 \%$ of the improvement in teaching variable was influenced by other factors. Meanwhile, capacity building only contributed $33.64 \%$ to improving the quality of teaching, while $66.36 \%$ improvement in the quality teaching was influenced by other factors.
However, both instructional leadership and capacity building contributed $44.82 \%$ to the improvement of the teaching qauality, while $55.18 \%$ of the improvement in teaching quality variable was influenced by other factors.

\section{B. Suggestion}

Teachers must strive to continuously build their capacity both at and outside of schools. This is because good teacher capacity will directly and indirectly improve the quality of teaching. In addition, principals should also have the ability to organize schools so that teachers may feel motivated to work well which in the end can lead to the improvement of their teaching quality.

\section{Recommendation}

Further researchers are suggested that they 1) conduct the research which are related to teaching quality using qualitative method so that the issues related to these variables can be explored more deeply; 2) use other variables other than the variables investigated in this study if they want to utilize the same research method with this research (quantitative).

\section{REFERENCES}

[1] S. Amri, Pengembangan dan Model Pembelajaran Dalam Kurikulum 2013. Jakarta: PT. Prestasi Pustakakarya, 2013, p. 282.

[2] W. Sanjaya, Kurikulum dan Pembelajaran. 1st ed. Jakarta: Prenadamedia group, 2008, p. 382

[3] D.K. Wardani dan M. Indriayu, "Kepemimpinan Pembelajaran Kepala Sekolah Untuk Meningkatkan Profesionalisme Guru Menghadapi Masyarakat Ekonomi Asean," Pros Semin Nas Pendidik Ekon FE UNY "Prof Pendidik dalam Din Kurikulum Pendidik di Indones pada Era MEA", no. 35, pp. 684-93, 2015.

[4] H. Usman dan N.E. Raharjo, "Strategi kepemimpinan pembelajaran menyongsong implementasi kurikulum 2013," J Cakrawala Pendidik, vol. 5 , no. $1,2013$.

[5] I. Gunawan, D.E. Kusumaningrum, and R.B. Sumarsono, "Investigation of Principal Leadership Based on Pesantren: Descriptive Study about Implementation of Human Resources Empowerment Models Based on Soft System Methodology," The 4th International Conference on Education and Management (COEMA 2019), vol. 381, pp. 255-8, 2020.

[6] D.E. Kusumaningrum, R.B. Sumarsono, dan I. Gunawan, "Pengaruh Kepemimpinan Pembelajaran, Kepemimpinan Perubahan, Kepemimpinan Spiritual, Budaya Sekolah, dan Etika Profesi terhadap Kinerja Mengajar Guru,” J Manaj dan Supervisi Pendidik, vol. 4, no. 3 , pp. 198-219, 2020.

[7] T. Bush and D. Glover, School Leadership: Concepts and Evidence Natl Coll Sch Leadersh, 2003, pp. 1-42.

[8] A. Wahyudi and W.S. Narimo, "Kepemimpinan Pembelajaran - Kepala Sekolah,” J Varidika, vol. 31, no. 1966, pp. 47-55, 2010

[9] P. Hallinger and J. Murphy, "Assessing the Instructional Managemen Behavior of Principals,” Elem Sch J., vol. 86, no. 2, pp. 217-47, 1985.

[10] A. Milen, Pegangan Dasar Pengembangan Kapasitas. Diterjemahkan secara bebas Yogyakarta: Pondok Pustaka Jogja, 2004

[11] Sutarto, Dasar-dasar kepemimpinan administrasi. Yogyakarta: Gadjah Mada University Press, 1991, p. 249.

[12] T. Morrison, Actionable Learning: A handbook for Capacity Building Through Case Based Learning. Asian Development Bank Institute, 2001 , p. 515 
[13] K. Sessions, "Building the capacity for change," EPA J., vol. 19, p. 15, 1993.

[14] Haryanto, Pengembangan Kapasitas Kelembagaan (Institutional Capacity Development) (Teori dan Aplikasi). Jakarta: Jakarta AP21 Nasional, 2014.

[15] R. Soeprapto, Pengembangan Kapasitas Pemerintah Daerah Menuju Good Governance (The Capacity Building For Local Government Toward Good Governance). Malang: Adm Publik F IA Univ Brawijaya, 2003.

[16] Departemen Pendidikan Nasional, Kamus Besar Bahasa Indonesia. Jakarta: Jakarta Balai Pustaka, 2002.
[17] S. Nasution, Didaktik Asas-Asas Mengajar, editor. Jakarta: Bumi Aksara, 1995, p. 191.

[18] H.E. Mulyasa, Standar Kompetensi dan Sertifikasi Guru. 1st ed. Mukhlis, Editor. Bandung: Remaja Rosdakarya, 2008, p. 276.

[19] N. Hanafiah dan C. Suhana, Konsep Strategi Pembelajaran. 1st ed. Hufron Sofiyanto, Editor. Bandung: Rafika Aditama, 2009, p. 236.

[20] Tim Dosen Administrasi Pendidikan UPI (D. Suhardan), Manajemen Pendidikan. 4th ed. Dr. M.B. Riduwan, Editor. Bandung: ALFABETA, cv, 2011, p. 368.

[21] Newmann, School Innovation, Pathway to The Knowledge Society. Australia: Departement of Education Australia, 2001. Available at: www.dest.govt.au 